\title{
UTILIZATION OF A LOCAL COEFFICIENT FOR IMMOVABLE PROPERTY TAX IN THE CZECH REPUBLIC
}

\author{
Lucie Formanová1, Martina Halamová1, Břetislav Andrlík ${ }^{1}$ \\ ${ }^{1}$ Department of Accounting and Taxes, Faculty of Business and Economics, Mendel University in Brno, \\ Zemědělská 1, 61300 Brno, Czech Republic
}

Link to this article: https://doi.org/10.11118/actaun202068060973

Received: 30. 7. 2020, Accepted: 15. 11. 2020

To cite this article: FORMANOVÁ LUCIE, HALAMOVÁ MARTINA, ANDRLÍK BŘETISLAV. 2020. Utilization of a Local Coefficient for Immovable Property Tax in the Czech Republic. Acta Universitatis Agriculturae et Silviculturae Mendelianae Brunensis, 68(6): 973-986.

\begin{abstract}
The paper deals with the issue of using a local coefficient as a tool to increase tax revenues of local government budgets in the Czech Republic. The local coefficient is defined as a corrective element increasing up to five times the immovable property tax that is $100 \%$ public budgets of local governments (municipalities) since 2009. As part of the paper, our own questionnaire survey was conducted across municipalities in the Czech Republic with the aim of identifying positive and negative consequences of application or non-application of this tax instrument at the level of local governments. Results of the research clearly demonstrate the use of the local coefficient, despite its potential high budget revenue is not high at all. In 2020, only 10.43\% municipalities from all over the Czech Republic applied it. A research survey conducted among municipalities focused on obtaining information on the reasons for the low use of the local coefficient. To this end, two research questions were formulated "Do municipalities have sufficient information on local coefficient issues?" and "May the introduction of a local coefficient result in a loss in the communal elections?" The questionnaire survey showed that 91\% municipalities know about their possibility to apply a local coefficient, but do not use it. Moreover, it was found that if the local coefficient is introduced at the right time or handling additional tax revenues of the municipality is transparent, its introduction does not affect the election result of the political party that declared it by a generally valid decree.
\end{abstract}

Keywords: immovable property tax, local coefficient, political cycle, municipal tax revenues

\section{INTRODUCTION}

The immovable property tax is regulated by Act No. 338/1992 Coll., On immovable property tax and is divided into two parts - land tax and tax on buildings and units. The tax is administered by locally competent tax authorities. Despite the fact that the entire revenue from immovable property tax flows into the budget of municipalities, those with the administration of this tax have no administrative costs (Andrlík, 2010a). Real estate tax does not represent a significant tax within the tax system of the Czech Republic in terms of volume. Based on data from the Ministry of Finance of the Czech Republic (2020a), they represented revenues from immovable property tax CZK 10.9 billion in 2019, while the total tax collection of territorial self-governing units amounted to more than CZK 320 billion. immovable property tax thus accounted for only $3.4 \%$ of the total tax revenues of local governments. In the state scale, immovable property tax is even more negligible, as it represents only a $0.8 \%$ share in the total tax revenues of the Czech Republic (Ministry of Finance of the Czech Republic, 2020b). The comparison 
of the role of immovable property tax in the tax systems of EU countries on the basis of the share of its collection in GDP is reported by Maličká (2017). Similarly, in the conditions of the Czech Republic it is solved by Andrlík (2010b). It is clear from the results of the comparison that the Czech Republic belongs to the countries where immovable property tax is of very low importance $(0-0.2 \%$ share of its revenue in GDP). So, it might seem that real estate tax does not play an important role in the Czech tax system, however, its importance lies especially in the benefit for municipalities.

Due to the fact that immovable property tax is the only tax in full flowing into municipal budget, it is an important tool for strengthening the independence of municipalities. Thanks for the possibility to influence the amount of tax, municipalities have the opportunity to better adapt their management to the characteristics of the municipality and to the current situation in it. The importance of the immovable property tax for municipalities is also evidenced by Andrlík and Formanová (2015, 2014), who, based on an examination of the relationship between immovable property tax and indebtedness of municipalities, came to the conclusion that in the case of elimination of the tax in question, the number of municipalities with insufficient income increased from $37 \%$ to $57 \%$. In other words, in the case of immovable property tax abolition, the number of municipalities with insufficient income would increase by 20 percentage points. For municipalities immovable property tax is an important part of their budgets.

Municipalities have several coefficients available for immovable property tax that affect either the rate tax (correction coefficient and coefficient 1.5), or the resulting tax liability (local coefficient). Until 2008, municipalities only had coefficients adjusting the tax rate available (both coefficients can be applied by municipalities even today), and their influence on the resulting amount of tax revenues of immovables was therefore minimal (Sedmihradská, 2013). The correction factor multiplies the rate taxes on building plots and residential buildings. Its basic amount is determined by law according to number of inhabitants and municipalities have the opportunity on the basis of a generally binding decree on one category increase or decrease by up to three categories. The advantage of the correction coefficient is the possibility of its different setting in individual local parts and distinguishing, for example, the centre from the peripheral parts. The second of the coefficients adjusting the tax rate is a coefficient of 1.5 that multiplies the tax rate for garages and taxable buildings intended for family recreation and business. Its amount is set at 1.5 and municipalities cannot change it, they can only introduce or cancel the coefficient, and only on the territory of the whole municipality.
The powers of municipalities in the field of immovable property tax increased significantly in 2009, when a local coefficient was introduced regulating not only the tax rate, but only the resulting tax rate liability. The local coefficient on the basis of $\$ 12$ of the immovable property tax Act, may be introduced by a generally binding decree at the amount of 2, 3, 4, or 5 for all land, buildings, and units throughout the municipality. Exceptions are arable land, hop gardens, vineyards, gardens, orchards and permanent grassland to which the local coefficient does not apply. Due to the fact that the local coefficient multiplies the resulting tax liability, it allows municipalities to increase their total immovable property tax revenues fivefold, thanks to which it has the greatest impact on the resulting tax collection of all corrective elements. The contribution of local coefficient for the municipalities is documented by Zdražil and Pernica (2018). In their paper, the authors confirmed the difference between municipalities applying a local coefficient and those that do not use it. Municipalities not using local coefficient are, according to the authors, more endangered by the trend of population aging (they face the overall population growth, but with a decrease in the working age population). At the same time, in these municipalities it is possible to monitor the decline in public services provided (education, health care, postal services). In contrast, municipalities using the local coefficient recorded in during the period under review, both the overall growth of population and the working age population and at the same time stagnation or even development of the public services provided. It is therefore possible to argue that in the case of introduction of a local coefficient and an increase in municipal income, their representatives have more options to invest these additional funds in the development of the municipality. In addition, the overall development of the municipality has the ability to attract other people of working age together with, e.g., entrepreneurs, and thus to contribute to the further development of the municipality (Zdražil and Pernica, 2018).

Due to reducing the negative impact of the increase in immovable property tax, many municipalities decide to introduce the local coefficient, for example according to the model of the surrounding municipalities. This fact is explained by Sedmihradská (2016) in an effort by politicians to imitate the behaviour of politicians from surrounding municipalities. Representatives of municipalities are aware of the fact that voters evaluate their actions on the basis of comparison with surrounding municipalities. Sedmihradská (2016) confirms that if the tax burden increases in the surrounding municipalities, voters come to the conclusion that it is also necessary for their municipality. 
For municipalities, the local coefficient is currently the most important instrument of its own tax policy. The possibility to influence the amount of immovable property tax that represents an indispensable part of their budgets for municipalities, provides not only the opportunity for municipalities to increase their revenues, but also to reduce their dependence on revenues from the budgetary determination of taxes and other transfers. Municipalities can apply the local coefficient for the eleventh year in a row, but its benefits are used by $10.43 \%$ of municipalities only (Financial Administration, 2020a). The aim of the paper, based on the respective survey between municipalities that do not apply the local coefficient, is to identify the elements explaining its low utilization. To fulfil the goal, research questions are first defined: Do municipalities have sufficient information on the possibilities of introducing a local coefficient? Can introduction of the local coefficient entail the loss in municipal elections? A research survey to identify the reasons for the low use of the local coefficient will be implemented in the form of a questionnaire survey that will reflect the first established research question. Then the second research question will be verified by a comparative analysis of election results in the years when it was possible to apply the local coefficient in the Czech Republic.

\section{MATERIALS AND METHODS}

Research survey in order to obtain information about the knowledge and attitudes of municipalities in relation to the local coefficient was carried out in the form of a questionnaire survey among municipalities not using this tool as of 1. 1. 2019 (total number of municipalities 5,655). For assembly A representative sample of financial administration data on the use of the local coefficient in 2019 (Financial Administration, 2019) and data from the Czech Statistical Office on the number of inhabitants was used in municipalities as of 1.1.2019 (CSO, 2019).

In order to carry out the questionnaire survey, a sample of 2,000 respondents was selected, taking into account the actual structure of Czech municipalities. The questionnaire was distributed in two rounds, each with 1,000 respondents. Municipalities with zero population were first excluded from those that do not apply the local coefficient (military districts) and the remaining municipalities were divided into three groups according to population, namely municipalities with less than 2,000 inhabitants, municipalities with 2,001-8,000 inhabitants and municipalities with more than 8,000 inhabitants (this categorization was chosen on the basis of the CZSO division as of 1. 1. 2013). Subsequently, the share of municipalities not using the local coefficient in individual regions was calculated and on the basis of of this share, the number of municipalities from individual regions was determined and included in the final

I: Distribution of municipalities in the representative sample

\begin{tabular}{|c|c|c|c|c|c|c|}
\hline \multirow{3}{*}{ Region } & \multicolumn{2}{|c|}{$\begin{array}{c}\text { Municipalities in the } \\
\text { Czech Republic without } \\
\text { local coefficient }\end{array}$} & \multicolumn{4}{|c|}{ Representative sample } \\
\hline & \multirow{2}{*}{$\begin{array}{c}\text { Number of } \\
\text { municipalities }\end{array}$} & \multirow{2}{*}[\%]{} & \multirow{2}{*}{$\begin{array}{c}\text { Number of } \\
\text { municipalities }\end{array}$} & \multicolumn{3}{|c|}{ According to population } \\
\hline & & & & Up to 2000 & $2001-8000$ & 8001 and more \\
\hline Central Bohemia Region & 947 & 16.7 & 167 & 155 & 9 & 3 \\
\hline South Bohemian Region & 588 & 10.4 & 104 & 97 & 6 & 1 \\
\hline Pilsen Region & 477 & 8.4 & 84 & 77 & 6 & 1 \\
\hline Karlovy Vary Region & 98 & 1.7 & 17 & 15 & 2 & 0 \\
\hline Ústí Region & 275 & 4.9 & 49 & 44 & 4 & 1 \\
\hline Liberec Region & 178 & 3.2 & 32 & 29 & 3 & 0 \\
\hline Hradec Králové Region & 410 & 7.3 & 73 & 67 & 4 & 2 \\
\hline Pardubice Region & 437 & 7.7 & 77 & 72 & 3 & 2 \\
\hline Vysočina Region & 683 & 12.1 & 121 & 116 & 3 & 2 \\
\hline South Bohemian Region & 632 & 11.2 & 112 & 100 & 10 & 2 \\
\hline Olomouc Region & 384 & 6.8 & 68 & 61 & 5 & 2 \\
\hline Zlín Region & 291 & 5.1 & 51 & 43 & 7 & 1 \\
\hline Moravian-Silesian Region & 255 & 4.5 & 45 & 34 & 9 & 2 \\
\hline & 5,655 & 100 & 1,000 & 910 & 71 & 19 \\
\hline
\end{tabular}

Source: Financial Administration, 2019, CSO 2019 
sample of 1,000 respondents. Within each region, the percentage representation of individual groups of municipalities (according to the number of inhabitants) was then calculated, which was used to determine the final number municipalities that were subsequently addressed. The distribution of municipalities in the representative sample is given In Tab. I. The specifically addressed municipalities were selected on the basis of a random selection. The return rate of the questionnaire was 23.35\%, a total of 467 responses were obtained after the implementation of both rounds of the questionnaire survey.

The questionnaire was divided into two parts, where the first part was used to determine the level of awareness of the municipality about the possibility of introducing the local coefficient. In the second part of the questionnaire there were reasons for not introducing a local coefficient. The intention was to find out for what reason the representatives of the municipality do not want to apply the local coefficient, alternatively why they are currently considering its introduction or the reason why they have abolished the local coefficient in the past.

Subsequently, there was a separate verification of the second research question that representatives of municipalities can be concerned about the negative reaction of citizens and therefore about re-election. This fear is undoubtedly justified. Negative reactions of citizens and a view of the community management that introduced measures with a direct impact on their disposable income is certainly a foreseeable and significant fact that has a direct influence on citizens' choices in elections. This research question was verified by comparing the results of municipal elections in the period when the local coefficient introduced in the given municipality and in the immediately following election period. So, if in both compared terms of the same political entity, this means that the concerns of representatives of municipality about their position in the management of the municipality were, depending on the introduction of the local coefficient, unnecessary. Conversely, in the case of different results in the compared years, an increase in immovable property tax could be one of the factors influencing voter decisions. To confirm this research question data provided by the financial administration containing information on the use of local coefficient in 2009-2019 (Financial Report, 2017, 2018, 2019, 2020a, 2020b) and the Czech Statistical Office information on election results (CSO, 2020b).

The authors further tested within this research question whether the result of the municipal elections could be affected by the number of years from the introduction of the local coefficient to the date of the next elections.This testing will be done in accordance with the theory of the political cycle.
This assumption will be verified by the Pearson correlation coefficient:

$r=\frac{\sum_{i=1}^{n}\left(x_{i}-\bar{x}\right)\left(y_{i}-\bar{y}\right)}{\sqrt{\sum_{i=1}^{n}\left(x_{i}-\bar{x}\right)^{2} \sum_{i=1}^{n}\left(y_{i}-\bar{y}\right)^{2}}}$,

where $x$ is equal to the share of municipalities in which the same political entity won the election before and after introduction of a local coefficient, on the total number of municipalities that introduced a local coefficient in the same period (in relation to the next elections). The variable $y$ represents the number of years until the elections. If the coefficient $r$ is in the interval $(0 ; 1>$, it is a positive dependence, the value 0 indicates the independence of the variables and the coefficient $r$ located in the interval $<-1 ; 0$ ) indicates a negative dependence.

\section{RESULTS}

Despite the potential for generating additional public budget revenues, the local coefficient among municipalities in the Czech Republic is not widely used. In 2019, the local coefficient was introduced in 610 municipalities out of the total number of 6,253 municipalities in the Czech Republic (Financial Administration, 2019; CSO, 2019). Since the possibility of applying the local coefficient, there has been an increase in the number municipalities that apply it. The identified decrease in the number of municipalities in 2010 was caused by legislative changes increasing the basic rates of immovable property tax and for some municipalities the application of the local coefficient was no longer necessary. In recent years, however, the number of municipalities that apply the local coefficient has relatively stagnated. In 2020, the number of municipalities using the local coefficient, it jumped to a total of 719 municipalities (Financial Administration, 2020a). However, this increase was mainly due to the introduction of a local coefficient in all 57 city districts of Prague (city districts of statutory cities the financial administration for statistics is considered separately). If the urban districts of statutory cities are not taken into account, the number of municipalities using the local coefficient was only 652 municipalities out of the total number of 6,253 as of 1. 1. 2020, which represents $10.43 \%$ of all municipalities in the Czech Republic (Financial Administration, 2020a; CSO, 2020a).

Municipalities that currently apply the local coefficient do so for a variety of reasons. One of the main motivations is to improve the management of the municipality and to obtain funds for operation and further development of the municipality. This fact is also confirmed by Janoušková and Sobotičová (2017), who add that municipalities often opt for the local coefficient in response to the growing costs associated with increase in the population 


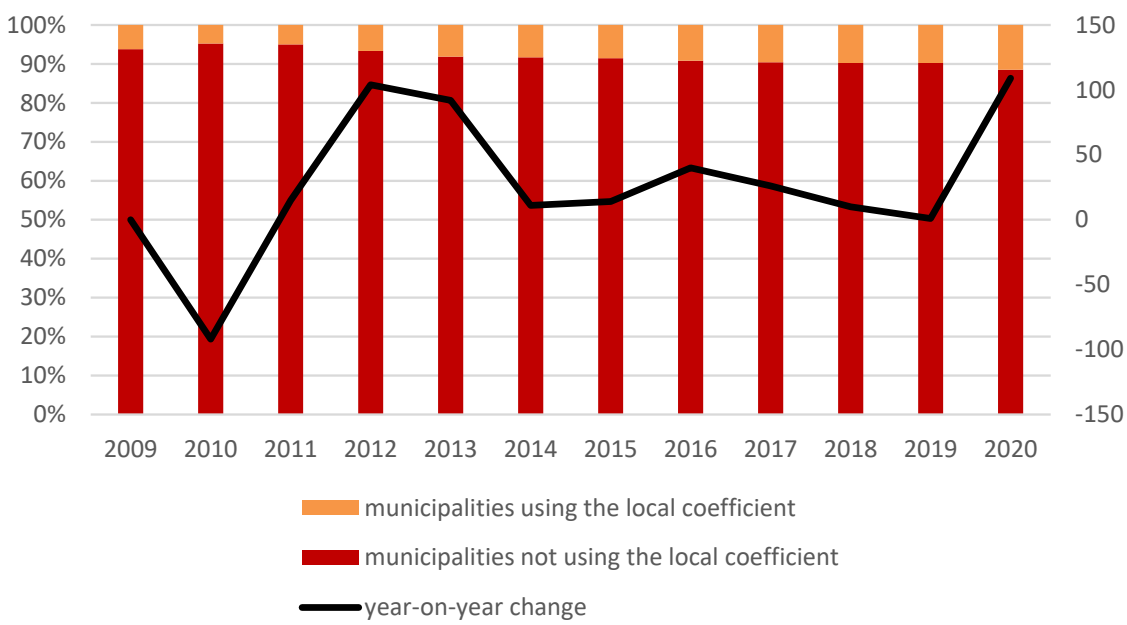

1: Development of the application of the local coefficient in 2009-2020

Source: Financial Administration, 2017, 2018, 2019, 2020a, 2020b

and growth of the municipality. It can therefore be said that these are rather larger municipalities and those in their vicinity. Specifically, for municipalities with less than 2,000 inhabitants, the local coefficient is applied by $8 \%$ of municipalities, for municipalities with 2,001-8,000 inhabitants $20 \%$ of municipalities and for municipalities with more than 8,000 inhabitants 38\% of municipalities (Financial Administration, 2020a; CSO, 2019). Thanks to the introduction of the local coefficient, municipalities also have the possibility to make the required investments that are currently mainly investments in roads, public greenery, sports or culture. The municipality that introduced the local coefficient for reasons of obtaining funding for its development, for example, Hradec Králové applying the coefficient of 3 from 2009. When the then mayor introduced the local coefficient, he stated that the main reason its implementation is the growing costs of the municipality caused by its expansion. He then wanted to use the additional funds mainly for the maintenance of the municipality, public greenery and for the repair of roads (Konečná, 2008).

Representatives of municipalities are often discouraged from introducing a local coefficient by fears of losing their political mandates. The main goal of politicians, including those at the municipal level, is primarily their re-election. They therefore implement their policy in such a way as to increase their chances of success as much as possible in the following elections. For this reason, politicians are taking popular action just before elections, while the unpopular ones postpone to the post-election period (Blais and Nadeau, 1992). They thus rely on the fact that the voter is influenced mainly by the current situation. According to the theory of political cycle, which explains Nordhaus (1975), the term of office of politicians characterized by austerity measures on the expenditure side at the beginning of this period, and increasing public spending just before the elections. The increase in local taxes is reversely implemented at the beginning of the term and represents an expansionary fiscal policy. The political cycle thus represents an alternation of restrictive and expansionary fiscal policies depending on the number of years remaining until the next election (Holman, 2017). Simultaneously Mandon and Casals (2019) state that in favour of increasing public spending, officials prefer short-term investments to long-term ones to ensure the visibility of the results of these measures as soon as possible.

Representatives of municipalities thus naturally avoid raising the immovable property tax that is perceived in society a priori negatively, even though it may affect the municipality quite positively in the future. At the same time, politicians take advantage of the fact that voters make decisions based on their current benefits, without considering the longterm consequences of political decisions. Voter at increase in public spending before the elections will not take into account in its decision - making the fact that the increase in expenditure will most likely have to be financed by an increase in the tax burden in the coming years. At the same time, if politicians want to increase the tax burden, they should do so as soon as possible after the elections, as this will provide funding to increase spending in the run-up to the elections. This theory can be applied even in the case of introducing a local coefficient. It is possible to assume that in the event of the introduction of a local coefficient in the first years of the term, the chances of re-election does not reduce, on the contrary, in the case of using the obtained funds for the implementation of investments in the second part of the term there may be an even higher chance of re-election.

The results of the questionnaire survey show that out of the total number of answers received i.e. 467, 427 municipalities know about the possibility of applying the local coefficient, i.e. 
91\%. Based on this result, it can be concluded that the low use of the local coefficient is not due to ignorance of legislative options in the immovable property tax Act, but for other reasons. As part of the evaluation of the questionnaires obtained, the following discrepancy was identified. A total of 8 municipalities (i.e. 2\%) stated that it was aware of the possibility of introducing a local coefficient and, in addition, respondents added that they actively use the local coefficient. Some of them also responded by referring to the relevant municipal decree regulating the use of the local coefficient. However, it must be stated that the said decrees regulated the application of other coefficients that the municipality may introduce for immovable property tax. For this reason, it can be stated that the municipalities confused the local coefficient in their answers with one of the other coefficients that can be applied to immovable property tax. This group of respondents (municipalities with incomplete knowledge) was therefore identified as a group of municipalities in which their representatives do not know the exact meaning of individual immovable property tax coefficients.

For a group of municipalities that do not know about their power to positively influence the amount of their tax revenues, a common feature is less than 2,000 inhabitants in the municipality (i.e. 7\% of municipalities). A similar fact was identified in municipalities with incomplete knowledge of the local coefficient. This can be explained by the possibilities and abilities of the representatives of smaller municipalities. The mayors of small municipalities (up to 2,000 inhabitants) are in most cases unqualified mayors, so in addition to the duties of the mayor, they also work in other professions, full-time. They thus have less time on the municipal agenda than the mayors who have been released, who can fully devote themselves to the duties associated with this function. Many politicians in smaller municipalities also do not have the appropriate legal, economic or education, and orientation in a very complicated Czech tax system can therefore cause them difficulties.

To the municipalities that did not know about the possibility of introducing a local coefficient (32 municipalities, i.e. 7\%), the authors of the questionnaire survey subsequently explained the issue and then asked whether they would consider the possibility of introducing a local coefficient on the basis of newly acquired information. The feedback was the fact that $41 \%$ (i.e. 13 municipalities) are considering the introduction of the local coefficient. Municipalities with this unqualified opinion most often mentioned the need for additional information as a justification, enabling a comprehensive view of the issue, including the effects of the introduction of the local coefficient for a particular municipality. In this connection, the authors of the research advised the given municipalities to use the locally competent tax administrators who provide this service. Another $9 \%$ of municipalities (i.e. 3 municipalities) answered in the affirmative that they would introduce a local coefficient. The argument, in addition to the possibility of increasing their tax revenues, is also the intention to place a greater burden on building land owners who do not carry out new construction and thus hinder the development of the municipality. This fact causes an outflow of potential residents looking for housing, and thus the impossibility of population growth in the municipality that is crucial for development and investment activities. A higher tax burden due to the local coefficient could thus force the owners of vacant building plots to sell them. It should also be noted that in the case of small municipalities (up to 1,000 inhabitants), the local coefficient is the only instrument within immovable property taxes that the municipality can effectively use to increase immovable property tax on building land. The correction coefficient specified in $\S 6$ par. 4 let. a) which increases the tax rate for building land, can be applied in a value higher than 1.0 for municipalities with more than 1,000 inhabitants. However, it is necessary to draw attention to the fact that the parameters of the introduction of the local coefficient do not allow focusing only on building plots, but have an impact on all immovables in the cadastre of the municipality.

As already mentioned, 91\% (427 municipalities) out of the examined sample are aware of the possibility of introducing a local coefficient. The obtained answers point to a significant predominance of the reaction (292 municipalities) that although the municipality knows about the possibility of applying the local coefficient, it has never considered its introduction. The possibility of introducing a local coefficient in the municipality was considered by 61 municipalities or it is being solved by 57 municipalities. The remaining 17 municipalities stated that they had applied the local coefficient in the past, but subsequently abolished it. The abolition of the local coefficient was caused by the aforementioned amendment to the immovable property tax Act that increased tax rates. The very construction of this tax brought significantly higher revenues of municipal budgets and it was a motive for municipalities to cancel an unpopular measure in the form of introducing a local coefficient

Municipalities that never considered introducing a local coefficient (292 municipalities) argued in $62 \%$ that the tax burden on their inhabitants was too high. Another $14 \%$ of municipalities stated that they do not need to increase tax revenues or have other secondary sources of financing. For less than $9 \%$ of municipalities, the introduction of a local coefficient would not be sufficiently advantageous, which was argued within the municipalities' own answers by a minimal increase in tax revenues and the 
unpopularity of the introduction of this coefficient. This answer has been identified mainly in smaller municipalities for which the immovable property tax does not represent significant revenues and the additional revenues from from the immovable property tax would thus not be such as to outweigh the political impact. A number of smaller A number of smaller municipalities also stated an effort to prevent a decline in the population moving to larger municipalities and to benefit residents living in rural areas who face a number of problems, such as insufficient civic amenities, transport inaccessibility, lack of jobs, etc. municipalities want to compensate for these disadvantages of living in villages with the lowest possible living costs.

For municipalities with information on the possibilities of introducing a local coefficient and at the same time stating that they had considered the possibility of introducing a local coefficient in the past (61 municipalities, i.e. 14\%), it was ascertained why it was not introduced in the end. More than half of these municipalities (54\%) argued for a high tax burden on their inhabitants. This argument, together with the unpopularity of the increase in immovable property tax and the political impassibility, was also mentioned by the respondents in their own answers (16\%). The remaining $30 \%$ of municipalities do not consider the local coefficient to be an advantageous source of municipal income or have found another source of obtaining municipal budget revenues.

Almost $40 \%$ of municipalities currently considering the introduction of a local coefficient (i.e. 22 municipalities) are studying this option due to the importance of immovable property tax for the municipal budget. Three of these municipalities stated in the questionnaire that they already apply the local coefficient with effect from 1.1.2020. At the same time, $25 \%$ of municipalities (14 municipalities) stated that they need to strengthen their tax revenues and immovable property tax is a tool under consideration. In addition, 13 municipalities plan to use the additional funds obtained by introducing a local coefficient to finance a specific investment plan in their municipality. As part of their own answers, 8 municipalities often mentioned specific ways in which they plan to use the funds obtained by raising the tax. These included, for example, repairs and maintenance of roads, waste management and the overall development of the municipality. One municipality also mentioned the above-discussed problem of unused building land hindering new construction and thus the development of the municipality.

The last group are municipalities that have used the local coefficient in the past, but subsequently decided to abolish it. There are a total of 17 municipalities. Of this number, 6 municipalities directly stated in the questionnaire that the reason for the abolition of the local coefficient was the fact that the amendment to the immovable property tax Act in 2010 significantly increased tax rates and thus, increased the municipality's tax revenues. From their point of view, the local coefficient thus became redundant. These are therefore municipalities that introduced the local coefficient immediately after its entry into force (i.e. in 2009). The following year, 2010, the aforementioned legislative change was made, as a result of which these municipalities abolished the local coefficient. Another group identified, were municipalities that stated in the questionnaire that the local coefficient was not as beneficial for the municipality as expected, when it was introduced. It can be undoubtedly stated here that the reason was a political decision. The remaining 2 municipalities cited the dissatisfaction of citizens as a reason for the abolition of the local coefficient that resulted from the high tax burden.

The second research question assumes that the low use of the local coefficient is caused by concerns of municipal representatives about the negative reaction of citizens. As deputies are elected to office, their remaining in office is strongly influenced by the favour of the electorate. Therefore, on the basis of this theory, politicians should make decisions primarily so that their activities do not meet with the reluctance of citizens. Raising taxes is generally considered a very unpopular measure, which is why politicians are trying to avoid it. But the question is whether their concerns are justified. It is true that raising taxes will inevitably provoke a negative response, but this resistance from citizens does not necessarily lead to non-election. In order to confirm or refute the impact of the introduction of a local coefficient on the re-election of municipal politicians, the results in the two immediately following municipal elections will be compared. Specifically, the winning political parties or other entities in the elections preceding the tax increase using the local coefficient and in the elections following this step will be compared. Municipalities using the local coefficient as of 1. 1. 2019 will be used for comparison and which did so in 2018 at the latest (municipal elections were held for the last time this year).

As of 1.1.2019, a total of 610 municipalities applied the local coefficient, of which 5 municipalities introduced the local coefficient up to this date. For this reason, these municipalities were excluded from the subsequent comparative analysis (the results of the municipal elections are not available). The investigated data sample therefore contains 605 municipalities in which the moment of the first introduction of the local coefficient was determined, see Tab. II. The result of the comparative analysis is that out of the total number of 605 municipalities (municipalities with a local coefficient introduced), 49\% of political entities (i.e. in 296 municipalities) were re-elected, despite the introduction of a local coefficient. Citizens have therefore again given 
II: Comparison of election results immediately preceding and following implementation of the local coefficient

\begin{tabular}{ccccc}
\hline $\begin{array}{c}\text { Year of introduction of the local } \\
\text { coefficient in the municipality }\end{array}$ & $\begin{array}{c}\text { Municipalities applying } \\
\text { the local coefficient }\end{array}$ & $\begin{array}{c}\text { Another winning } \\
\text { political party }\end{array}$ & $\begin{array}{c}\text { The same winning } \\
\text { political party }\end{array}$ & Share in \%* \\
\hline 2009 & 186 & 101 & 85 & 46 \\
2010 & 84 & 56 & 28 & 33 \\
2011 & 27 & 14 & 13 & 48 \\
2012 & 102 & 46 & 56 & 54 \\
2013 & 87 & 40 & 47 & 36 \\
2014 & 25 & 16 & 9 & 77 \\
2015 & 13 & 3 & 10 & 0 \\
2016 & 0 & 0 & 0 & 62 \\
2017 & 68 & 26 & 42 & 46 \\
\hline 2018 & 13 & 7 & 6 & 49 \\
\hline Total & 605 & 309 & 296 & 54 \\
\hline
\end{tabular}

Note: The share of the same winning political party in the total number of municipalities applying the local coefficient Source: Financial Administration, 2017, 2018, 2019, 2020a, 2020b; CSO, 2020b

a sufficient number of votes to win to those political entities that have introduced a local coefficient. On the contrary, in the remaining 309 municipalities a political party other than the one that won the previous elections won the municipal elections following the introduction of the local coefficient. Based on these results, it can be concluded that politicians who introduce a local coefficient have approximately the same chance of re-election as politicians who have not introduced a local coefficient. Results of comparative analysis are listed in Tab. II.

The performed comparative analysis does not provide completely unambiguous information related to the moment of introduction of the local coefficient and the date of municipal elections. There may be a situation where the local coefficient introduces the municipality immediately after obtaining a political mandate after the elections and by the deadline for the next election cycle, voters (citizens) will forget about this negative step affecting their disposable income. This fact is related to the theory of political cycles. This is based on the assumption that voters will support those political entities that will provide them with. the greatest personal benefit. Political entities, which primarily try to gain the favour of voters, then implement a pleasing policy that will meet with a positive response from citizens. In addition, this theory considers the presence of so-called voter myopia (Volejníková, 2005). When deciding on elections, voters primarily consider the current situation, i.e. the situation at the time of the elections. Shortsighted voters do not look at the impact of political decisions in the future, but at the current benefits they derive from decisions. These assumptions suggest that politicians implement other types of policies depending on the distance from the next elections. They are trying to implement these unpopular steps, as well as raising taxes, especially shortly after the election, when voter's dissent typically does not jeopardize their position. On the contrary, just before the election, politicians promote popular policies, such as reducing taxes or increasing public spending, in an effort to win the electorate. Citizens will then "forget" the unpopular steps taken in the first part of the parliamentary term and evaluate policies on the basis of their current positive measures. At the same time, shortsighted voters do not realize that tax cuts and spending increases are in most cases unsustainable in the long run, and politicians will sooner or later have to resort, at least to some extent, to those unpopular steps to balance the public budget.

In the case of the introduction of a local coefficient, the presence of a political cycle would mean that municipal representatives, who decided to increase immovable property tax in this way immediately after the elections, were re-elected in more cases than those who decided to do so just before the elections. To verify this theory, a correlation coefficient will be calculated to determine the relationship between the re-victory of a political party (a particular politician in the case of smaller municipalities) and the number of years since the introduction of the local coefficient until the next election. Specific values are listed in Tab. III.

From Tab. III it is evident that if the local coefficient was introduced in the year of the elections, only $35 \%$ of political entities were reelected. This consequence of the introduction of a local coefficient in connection with the theory of the electoral cycle can also be supported by the fact that the immovable property tax is payable in May and the elections to the municipal councils take place in October. Thus, the introduction of 
III: Comparison of election results depending on the number ofyears since the introduction of the local coefficient unti municipal elections

\begin{tabular}{lccc}
\hline Number of years until the next elections Number of municipalities Victory of the same political party & Share in \% \\
\hline 3 years & 40 & 23 & 58 \\
2 years & 102 & 56 & 55 \\
1 year & 341 & 174 & 51 \\
Year of the elections & 122 & 43 & 35 \\
\hline
\end{tabular}

Source: Financial Administration, 2017, 2018, 2019, 2020a, 2020b; CSO, 2020b

IV: Comparison of election results depending on the amount of the local coefficient

\begin{tabular}{cccc}
\hline The amount of the local coefficient & Number of municipalities Victory of the same political party & Share in \% \\
\hline 5.0 & 17 & 7 & 41 \\
4.0 & 13 & 8 & 62 \\
3.0 & 70 & 38 & 54 \\
2.0 & 505 & 243 & 48 \\
\hline
\end{tabular}

Source: Financial Administration, 2017, 2018, 2019, 2020a, 2020b; CSO, 2020b

a local coefficient in the election year will affect voters only a few months after noticing an increase in immovable property tax. Conversely, in the case of the increase in immovable property tax in the years immediately following the elections, $58 \%$ of political entities defended their victory, which is again confirmed by the theory of political cycles.

From the data given in Tab. III, the Pearson correlation coefficient (1) was calculated, determining the dependence between the number of years until the next municipal elections and the electoral victory of the political party that introduced the coefficient. The correlation coefficient takes the value of 0.92. It is therefore a very strongly positive dependence. Based on the result of the Pearson correlation coefficient, it can be argued that the success of politicians introducing a local coefficient is strongly dependent on when they introduce the local coefficient. In addition to verifying the political cycle, in the case of immovable property tax, it is possible to examine whether the level of the local coefficient affects the election result (i.e. re-election). In general, it can be assumed that the higher the local coefficient introduced by politicians, the less likely they were to be re-elected, because they increased the tax burden on voters more significantly. The results of the performed examination are given in Tab. IV.

Based on the results shown in Tab. IV it can be stated that the value of the local coefficient does not have a significant effect on the victory of the same political party. The highest value of the revictory of $62 \%$ was achieved with the introduction of a coefficient of 4 . More than half of the political parties also won the municipal elections again if the value of the local coefficient was 3. However, this general assumption can be confirmed in the case of the introduction of a local coefficient of 5 , where only $41 \%$ of political leaders were re-elected.

\section{DISCUSSION}

Within the definition of the goal of the paper, research questions were defined. The first research question is: Do municipalities have sufficient information on the possibilities of introducing a local coefficient? The processed results of the questionnaire survey clearly show that municipalities are sufficiently informed in this area. In relative value, this is $91 \%$ of municipalities from the examined sample of municipalities in the Czech Republic that know about the possibility of applying a local coefficient. Financial authorities also play an indisputable role in informing municipalities. The individual tax authorities provide municipalities with advice not only on the issue of immovable property tax, but also that the tax authorities are able to provide calculations of the effects of the application of individual local coefficients on the resulting tax collection Some financial authorities or territorial workplaces act as educators, who inform the representatives of municipalities about their rights and obligations within the immovable property tax, for example by organizing professional lectures or sending informational messages. The tax authorities do so mainly to ensure the sending of generally binding decrees regulating immovable property tax by municipalities. For this reason, the results of the questionnaire survey were further expanded to include research in the form of direct interviews in which representatives of financial authorities who provide immovable property tax administration were contacted. During the interviews, it was ascertained whether the tax authorities inform the representatives of the municipalities about their powers within the immovable property tax, or how they do so. The result of the research was the confirmation of the above fact about the activities 
of financial authorities in the position of educator and at the same time can confirm their undeniable role that has an impact on such a high percentage of municipalities knowing their powers in this area. In conclusion, it can be stated that the statement assuming the lack of information of municipalities that would be the result of a low percentage of use of this tool in the conditions of the Czech Republic, can be rejected.

The second research question is: Could the introduction of a local coefficient result in the loss in municipal elections? Based on the results achieved, it can be argued that the possible fears of the ruling political leaders of losing the next elections in the case of the introduction of a local coefficient are not entirely justified. This conclusion follows from the performed comparative analysis of election results in Tab. II. In about half of the cases, voters gave the most votes in the election to those deputies who increased the immovable property tax. However, the period taking into account the introduction of a local coefficient that reflects the number of years until the forthcoming municipal elections, plays an important role. This assumption was tested on a sample of municipalities utilizing a local coefficient using Pearson's correlation coefficient, the results of which point to a strongly positive relationship between the time to the upcoming municipal elections and the victory of the political party that introduced the local coefficient. If the representatives of the municipality decide to introduce a local coefficient for immovable property tax, they should, according to the theory of political cycles, do so as soon as possible after their elections, as they increase their chances of success in the next elections. At the same time, if politicians decide to do so, they will receive additional funds to finance investments or other increases in municipal spending in the run-up to the election, which, according to the theory of political cycles, will make voters more inclined. which, according to the theory of political cycles, will win voters' favour. However, it does not exclude the existence of other factors that could affect the amount of the local coefficient.

In addition, it has been shown that a higher value of the local coefficient does not have a significant negative effect on the re-election of political leaders. In municipalities using coefficients of 3 and 4, the same political party won the elections in the two monitored election periods more often than with the introduction of a local coefficient of 2 . A possible explanation for this may be the fact that municipalities introducing a higher local coefficient are often municipalities with a significant share of revenues from this property tax, and it is easier for political representatives to defend a higher tax liability. Another fact may be the reality that with high taxation of immovables due to its location in the cadastre of the municipality of industrial or tourist-attractive immovables, local residents are often compensated for higher taxation. Municipalities using the presence of industry can be found especially in the Ostrava region or the Ústí region. In the case of tourist regions of the municipality, the local coefficient is introduced especially due to obtaining funds from nonresidents who stay in the municipality, but the budgetary determination of taxes does not consider their presence. By introducing a local coefficient, municipalities can ensure the financing of additional expenses caused by tourism in the municipality. The influence of tourism on the introduction of the local coefficient is indicated by the concentration of municipalities applying the local coefficient in the districts of Český Krumlov (Lipno and Šumava region), Jeseník (Hrubý Jeseník region) or Česká Lípa (the Kokořínsko-Mácha region and the Lusatian Monuntains). In both cases, municipalities often choose local coefficients in the highest possible values and compensate the local population for the tax, for example by providing funds for maintenance and repair of immovables. As an example of such municipalities can be Lipno and Vltavou, Frýdlant nad Ostravicí and Ostružná (local coefficient 4) or Boží Dar, Dolní Morava or Dukovany (local coefficient 5). Their main goal is to burden businesses or non-residents and, thanks to newly acquired funds, to improve conditions for permanent residents.

Voters' positive views on higher taxation can also be influenced by the way the municipality manages additional finances. If the municipality significantly increases the immovable property tax, but at the same time invests funds in projects considered by the inhabitants of the municipality as meaningful, voters may conclude that despite the increase in local tax, deputies manage well and therefore, decide to re-elect them.

\section{CONCLUSION}

The aim of the paper was to identify the elements explaining the low utilization of the local coefficient. The questionnaire survey showed that municipalities most often do not use local coefficients due to the aversion of citizens to increasing the tax burden or believe that the tax burden of citizens after the implementation of the local coefficient would be inadequately high, which would result in unpopularity. Many municipalities do not introduce a local coefficient due to the insignificance of the immovable property tax for the municipal budget. According to the authors' survey from the data of the Ministry of Finance of the Czech Republic (2020c), it can be stated that in municipalities with a smaller population (100 to 500) the discussed tax often shares less than $0.1 \%$ to total revenues that 
represents only hundred thousand crowns. In the case of municipalities with the smallest smallest population (up to 100), the tax revenue is often only in the order of tens of thousands of crowns. For these municipalities, the introduction of a local coefficient will not bring about a significant increase in their total income, and is therefore considered unnecessary. It is also important to mention in this context the fact that many municipalities, due to their size given by the number of inhabitants, provide their services only at a very basic level. Some municipalities lack all civic amenities, including shops, schools and cultural centres, and at the same time it is not possible for municipalities to provide these services. However, in addition to the above arguments supporting the intention not to introduce local coefficients, it should be noted that it is a very effective tool in terms of administrative complexity. However, additionally obtained tax revenues in the municipality's budget (even in insignificant amounts) can lead to an improvement in the quality of life in the municipality that will be positively perceived in the subsequent municipal elections. At the same time, the paper showed that the impact of the introduction of a local coefficient on election results is insignificant. This conclusion can be further confirmed by the proven result in connection with the theory of the political cycle that if the representatives of the municipality correctly time the decision to introduce coefficient, this decision does not have a significant impact on voters' decisions. However, there are some limits of our research. Within the analysis there were not considered other factors which could affect the elections results. It could be potential subject of other research in that area.

It is quite obvious that the representatives of the municipalities naturally fear the negative reaction of the voters which usually follows the tax increase. However, it is necessary to mention the fact that negative opinions are usually the ones that are heard the most. When people are happy with something, they often do not express their attitudes. On the contrary, if people disagree with something, they are not afraid to share their opinions with others. Thus, the representatives of the municipality may come to the conclusion that the majority of the population is strongly outraged by the decision, although in fact, the majority of the population may not perceive the decision so strongly negatively. A specific example of a strong negative reaction of citizens after the introduction of the local coefficient of 3 in 2009 can be Hradec Králové (Konečná, 2008). However, surveys of citizens' satisfaction with life in the municipality show that since 2005 more than $90 \%$ of respondents have been regularly satisfied with life in Hradec Králové, and this number is constantly increasing. Despite the high tax burden, the citizens of Hradec Králové have long been among the most satisfied citizens in comparison with other municipalities conducting similar surveys. Citizens characterized the municipality as "quiet, nice, pleasant and clean, with a good environment" and at the same time highlighted sports and cultural activities (Hradec Králové, 2017). It is very probable that the municipality was able to create this environment thanks to the introduction of a local coefficient and an increase in income from immovable property tax. Although citizens pay extra for this local tax, these costs are offset by an improvement in their quality of life in their place of residence.

As mentioned, raising the tax on immovable property is considered a very unpopular measure, leading politicians to worry about their position in the event of a tax increase. Although a comparison of election results showed that the introduction of a local coefficient at the beginning of the election period did not lead to non-election in subsequent elections in most cases, it can be assumed that the concerns of deputies will remain the same. The main reason is the fact that some citizens will always react in in disapproval. Therefore, it is essential that politicians try to minimize this part, not to eliminate it. An increase in the share of citizens perceiving the increase in immovable property tax: by the local coefficient in a neutral or even positive way can be achieved through various approaches that can be mentioned in four complementary items:

- compensation,

- communications,

- awareness,

- participation.

Compensation is a common tool used by municipalities to reduce the negative effects of introducing a local coefficient. In most cases, compensation is provided by those municipalities that sets the local coefficient to the highest values. Their goal is to benefit local residents at the expense of holidaymakers or entrepreneurs and companies. The most common forms of compensation include the abolition of some local fees, the creation of various funds from which the citizens of the municipality can draw funds or a partial or full refund of the tax paid if certain conditions are met. For example, in Dolní Morava, applying a local coefficient of 5, permanent residents can request a gift in the amount of one hundred per cent of the tax paid for property maintenance. In this way, the representatives of the municipality also want to motivate citizens to take care of their immovable properties, as only those who take proper care of their immovables and surroundings (Latislav, 2020). 
Many municipalities decide to introduce a local coefficient and at the same time abolish the local fee, especially the municipal waste fee. The main reason is the administrative simplicity of this solution, because while local fees are administered by the municipality, immovable property tax is administered by the tax authorities and the municipality does not incur any costs for its collection. At the same time, an increase in immovable property tax will bring more income than the local tax in most cases. According to Radvan (2019), it is ideal for a municipality to have only one local tax - immovable property tax, precisely because of the zero costs of its administration on the part of the municipality and the ability to cover the costs of waste management if a local coefficient is introduced.

If the municipality does not want or cannot compensate the citizens for the higher tax in any way, it is important that it communicates and informs the citizens about this issue. Communication with citizens and explanation of the essence of the implemented measures leads to a better understanding of the intention of the representatives of the municipality and to the subsequent positive or neutral perception of the initially introduced negative measure.

In the case of immovable property tax, it can be assumed that a large proportion of citizens are unaware of the fact that this is the sole income of the municipality, and all the funds can be used for the purposes of the municipality where the taxpayer lives. By providing information on the meaning of this tax for municipal budgets and how the money collected will be used, it can increase taxpayers' impression of the importance and benefits of this tax. Last but not least, many citizens perceive positively the possibility of their involvement in the decision-making process. The fact that citizens have the opportunity to determine, at least in part, how immovable property tax revenues will be treated and what this money will be used for reduces the negative perception of immovable property tax. Despite the clearly proven fact that the use of the local coefficient in the conditions of the Czech Republic is insignificant, the outputs of this paper can be used in arguing its basic positive contribution. Simply put, increasing the local coefficient leads to increase of tax revenues of municipal budgets and thus creates a significant potential in investments in transport (e.g. repairs of roads, construction of new parking spaces, bike paths, etc.), modifications of public spaces, maintenance and expansion of greenery or expansion of sports and cultural activities in the municipality. This statement is gaining in importance, especially in the case of larger municipalities, where an increase in the local coefficient will lead to a significant increase in tax revenue. Improving services in all these areas is also in demand among the inhabitants of the municipality, as evidenced, for example, by the results of voting for participatory budgets (e.g. Brno - Brno City Council, 2020). From the conducted questionnaire survey within the open answers, the representatives of the municipalities often mentioned the requirement for the possibility to differentiate the size of taxation into individual parts of the municipality or tax subjects. Currently (July 2020) there is a government proposal for tax changes for 2021 which also proposes an amendment to the Immovable Property Tax Act allowing municipalities to introduce a local coefficient for individual parts of the municipality (Chamber of Deputies, the Parliament of the Czech Republic, 2020). If approved, this change would allow, for example, municipalities in industrial and tourist areas to burden only the industrial zones or the tourist part of the municipality with a local coefficient, and reduce their administrative costs of providing compensation to local citizens. This fact is also stated by the Minister of Finance of the Czech Republic JUDr. Alena Schillerová, Ph.D. (Vintrlík, 2020). At the same time, thanks to the possibility of differentiating parts of the municipality, the municipalities could better solve the above-described issue of building land and introduce a local coefficient only in the area of planned construction. In addition, this step would lead to a simplification of the whole system, which would undoubtedly be a positive benefit for the representatives of the municipalities, who, for example, have the above-determined fears of re-election.

\section{REFERENCES}

ANDRLÍK, B. 2010. Vývoj inkasa transferových daní v letech 1993 až 2009 v České republice. Acta Universitatis Agriculturae et Silviculturae Mendelianae Brunensis, 58(6): 21-32.

ANDRLÍK, B. and FORMANOVÁ, L. 2014. Importance of the recurrent tax on immovable property in the tax systems of EU countries. Acta Universitatis Agriculturae et Silviculturae Mendelianae Brunensis, 62(6): 1213-1220.

ANDRLÍK, B. and FORMANOVÁ, L. 2015. The role of the tax on immovable property in the municipal budgets in the Czech Republic. Acta academica karviniensia, 2: 5-17.

BLAIS, A. and NADEAU, R. 1992. The electoral budget cycle. Public Choice, 74(4): 389-403.

ČSÚ. 2019. Počet obyvatel v obcích - k 1. 1. 2019. Český statistický úřad. [Online]. Available at: https:// www.czso.cz/csu/czso/pocet-obyvatel-v-obcich-za0wri436p [Accessed: 2020, July 13]. 
ČSÚ. 2020a. Počet obyvatel v obcích - k 1. 1. 2020. Český statistický úřad. [Online]. Available at: https:// www.czso.cz/csu/czso/pocet-obyvatel-v-obcich-k-112019 [Accessed: 2020, July 13].

ČSÚ. 2020b. Výsledky voleb a referend. Český statistický úřad. [Online]. Available at: https://volby.cz/ [Accessed: 2020, July 24].

MAGISTRÁT MĚSTA BRNA. 2020. Dáme na vás, participativní rozpočet. [Online]. Available at: https:// damenavas.brno.cz/ [Accessed: 2020, July 24].

FINANČNí SPRÁVA. 2017. Informace poskytnuté dle zákona č. 106/1999 Sb., (44/2017). Finanční správa. [Online]. Available at: https://www.financnisprava.cz/cs/financni-sprava/generalni-financnireditelstvi/uredni-deska-gfr/poskytnute-info-dle-zakona-106-1999sb/2017 [Accessed: 2020, April 22].

FINANČNÍ SPRÁVA. 2018. Informace poskytnuté dle zákona č. 106/1999 Sb., (1/2018). Finanční správa. [Online]. Available at: https://www.financnisprava.cz/cs/financni-sprava/generalni-financnireditelstvi/uredni-deska-gfr/poskytnute-info-dle-zakona-106-1999sb/2018 [Accessed: 2020, April 22].

FINANČNÍ SPRÁVA. 2019. Informace poskytnuté dle zákona č. 106/1999 Sb., (050/2019). Finanční správa. [Online]. Available at: https://www.financnisprava.cz/cs/financni-sprava/generalni-financnireditelstvi/uredni-deska-gfr/poskytnute-info-dle-zakona-106-1999sb/2019 [Accessed: 2020, April 22].

FINANČNÍ SPRÁVA. 2020a. Informace poskytnuté dle zákona č. 106/1999 Sb., (002/2020). Finanční správa. [Online]. Available at: https://www.financnisprava.cz/cs/financni-sprava/generalni-financnireditelstvi/uredni-deska-gfr/poskytnute-info-dle-zakona-106-1999sb/2020 [Accessed: 2020, April 22].

FINANČNÍ SPRÁVA. 2020b. Seznam obcí uplatňující místní koeficient v roce 2009. [Elektronická pošta]. 5. 2. 2020 [Cited 22. 4. 2020]. Interní zdroj MFČR, č. j.: 7273/20/7700-00130-202098.

HOLMAN, R. 2017. Dějiny ekonomického myšlení. 4 ${ }^{\text {th }}$ Edition. Beckovy ekonomické učebnice. Prague: C. H. Beck.

HRADEC KRÁLOVÉ. 2017. Indikátor A1 spokojenost občanů s místním společenstvím. Hradec Králové. [Online]. Available at: https://www.hradeckralove.org/indikator-a1-spokojenost-obcanu-s-mistnimspolecenstvim/d-55020 [Accessed: 2020, May 15].

JANOUŠKOVÁ, J. and SOBOTIČOVÁ, Š. 2017. Property Tax in the Regions of the Czech Republic. E+M Ekonomie a Management, 20(4): 120-134.

KONEČNÁ, D. 2008. Náklady na bydlení v Hradci se mají zvyšovat. Hradec Kralove.cz [Online]. Available at: https://zpravy.hradeckralove.cz/naklady-na-bydleni-v-hradci-se-maji-zvysovat-11050/ [Accessed: 2020, May 5].

LATISLAV, R. 2020. Dolní Morava zvedla daň z nemovitosti na pětinásobek, těží ze ski resortu. iDNES. cz. [Online]. Available at: https://www.idnes.cz/pardubice/zpravy/dolni-morava-dan-z-nemovitostipardubicky-kraj-resort-sneznik.A200117_144347_pardubice-zpravy_lati [Accessed: 2020, May 5].

MANDON, P. and CAZALS, A. 2019. Political Budget Cycles: Manipulation by Leaders Versus Manipulation by Researchers? Evidence from a Meta-Regression Analysis. Journal of Economic Surveys, 33(1): 274-308.

MALIČKÁ, L. 2017. The Role of Immovable Property Taxes in the EU Countries-Taxes on Land, Buildings and Other Structure in Sub-National Tax Revenues Under the Conditions of Tax Decentralization. Acta Universitatis Agriculturae et Silviculturae Mendelianae Brunensis, 65(4): 1383-1392.

MINISTERSTVO FINANCÍ ČR. 2020a. Územní samospráva, druhový rozklikávací rozpočet pro př́imy. MON1TOR. [Online]. Available at: https://monitor.statnipokladna.cz/uzemni-samosprava/rozpocet/ prijmy-druhovy?rad=j\&obdobi=1912 [Accessed: 2020, July 13].

MINISTERSTVO FINANCÍ ČR. 2020b. Schválený druhový rozklikávací rozpočet pro př́imy. MON1TOR. [Online]. Available at: https://monitor.statnipokladna.cz/statni-sprava/schvaleny-rozpocet/prijmydruhovy?rad=j\&obdobi=1912 [Accessed: 2020, February 14].

MINISTERSTVO FINANCÍ ČR. 2020c. Monitor - kompletní přehled veřejných financí. [Online]. Available at: https://monitor.statnipokladna.cz/ [Accessed: 2020, July 13].

NORDHAUS, W. D. 1975. The Political Business Cycle. Review of Economic Studies, 42(2): 169.

POSLANECKÁ SNĚMOVNA PARLAMENTU ČR. 2020. Sněmovní tisk 910. Poslanecká sněmovna Parlamentu $\check{C} R$. [Online]. Available at: https://www.psp.cz/sqw/historie.sqw?o=8\&t=910 [Accessed: 2020, July 15].

RADVAN, M. 2019. Municipal charges on communal waste: do they compete with the immovable property tax. Journal of Financial Management of Property and Construction, 24(2): 148-165.

SEDMIHRADSKÁ, L. 2013. Property Tax Autonomy of Municipalities in the Czech Republic and Slovakia. Acta Oeconomica Pragensia, 21(1): 68-80.

SEDMIHRADSKÁ, L. 2016. Municipal Tax Autonomy and Tax Mimicking in Czech Municipalities. Lex Localis - Journal of Local Self-Government, 14(1): 75-92.

CZECH REPUBLIC. 1992. Act. No. 338/1992 Coll., on Immovable Property Tax, as amended [in Czech: Zákon č. 338/1992 Sb., ve znění pozdějších předpisů]. In: Sbírka zákonů České republiky.

VINTRLÍK, J. 2020. Peníze místo stravenek a vyšší příjmy obcím. Vláda schválila daňový balíček. Ministerstvo finance České republiky. [Online]. Available at: https://www.mfcr.cz/cs/aktualne/ tiskove-zpravy/2020/penize-misto-stravenek-a-vyssi-prijmy-ob-38768 [Accessed: 2020, July 26]. 
VOLEJNÍKOVÁ, J. 2005. Moderní kompendium ekonomických teorii: od antických zdrojů až po třetí tisíciletí. Prague: Profess Consulting.

ZDRAŽIL, P. and PERNICA, B. 2018. Property Tax and Quality of Life in the Czech Municipalities: Does the Policy of Raising Local Coefficiet Imply Potencial or Risk for Development. Rewiev of Economic Perspectives, 18(2): 123-136.

\section{Contact information}

Lucie Formanová: lucie.formanova@mendelu.cz

Martina Halamová: xhalamov@node.mendelu.cz Břetislav Andrlík: xandrlik@mendelu.cz 